\title{
The construct of subjective occupational well-being: Russian sample testing
}

\author{
Alexander A. Oboznov ${ }^{1}$, Daria L. Petrovich², \\ Irina V. Kozhanova ${ }^{3}$, Yulia V. Bessonova ${ }^{1}$ \\ ${ }^{1}$ Institute of Psychology of Russian Academy of Sciences \\ 13 Yaroslavskaya St, bldg. 1, Moscow, 129366, Russian Federation \\ ${ }^{2}$ State Academic University for Humanities \\ 26 Maronovskij Alleyway, Moscow, 119049, Russian Federation \\ ${ }^{3}$ Federal State Institute of Advanced Finance Professional Training \\ "Federal Tax Service Training Institute" \\ 48 Gruzinskaya St, Nizhny Novgorod, 603950, Russian Federation
}

\begin{abstract}
Subjective occupational well-being, as shown by the authors of this article, is one of the key conditions for occupational health and career longevity in our time. Along with this, existing models associate the achievement of occupational well-being with the realisation of aspirations for personal self-development and autonomy subject to professional competence and favourable emotional and psychosomatic states prevailing in a comfortable working environment. However, these models do not take into account the social and occupational relevance of actors as a factor in their occupational well-being, although any professional occupation is initially aimed at obtaining the results required by society. Any activity, the results of which do not meet the expectations and requirements of society, become unclaimed, the demand for its participants is lost, and the problem of their subjective occupational wellbeing becomes irrelevant. Therefore, it would be incorrect to consider the assessment of personal occupational well-being without correlating it with the assessment of personal social and occupational relevance. As shown in the article, human well-being should also be considered in ethnocultural terms. In this regard, the aim of the present study was to provide a theoretical and empirical justification for the construct of subjective occupational well-being, including the component of social-occupational relevance, using a Russian sample. To verify this point, we conducted an empirical study that involved 285 employees of Russian territorial tax authorities. Their employment records in the tax service ranged from 1 to 34 years, with less than three years in $18 \%$ of the sample. Their age range was $22-62$ years, with $25 \%$ of the sample on the right side of thirty. The sample included $70 \%$ of women and $30 \%$ of men. The study used The Professional Demand Questionnaire (Kharitonova, 2014), The Occupational Well-Being Inventory (Rut, 2016), The Prevalent Positive Emotional State Questionnaire (Kulikov, 2003), and the single-scale questionnaires - The Utrecht Work Engagement Scale (UWES-17) and Dutch Boredom Scale (DUBS) in Russian adaptation (Schaufeli, Diystra, Ivanova, 2015). The research methods included factor analysis (principal component analysis, varimax rotation) and one-way analysis of variance (ANOVA). The results of the factor analysis showed that the newly proposed construct of subjective occupational well-being included
\end{abstract}

(C) Oboznov A.A., Petrovich D.L., Kozhanova I.V., Bessonova Yu.V., 2020

(c) (i) This work is licensed under a Creative Commons Attribution 4.0 International License https://creativecommons.org/licenses/by/4.0/ 
three independent but, at the same time, interrelated components. The first component $(27 \%$ of the variance explained) contained a set of self-esteems of the employees that reflected their awareness of their social and occupational relevance ("I, as a competent and sought-after professional"). The second component (19\%) contained self-esteems that reflected the sustainable dominance of positive emotional states among the employees. And the third component (14\%) contained self-esteems that reflected the degree to which the employees realised their aspirations for professional growth, satisfaction with their professional achievements and relationships in the work team. Two areas of further research on the problem of subjective occupational wellbeing are considered relevant. One area is the further elaboration of the ideas of the resource approach for developing and maintaining employees' subjective occupational well-being (Schaufeli, Bakker, Van Rhenen, 2009). The other area is research in the framework of cross-cultural and cross-occupational approaches (Brauchli et al., 2013).

Key words: subjective occupational well-being, social and occupational relevance, construct, tax service

\section{Introduction}

The concept of 'well-being' has an interdisciplinary status and is used in philosophy, sociology, economics, medicine, pedagogy, psychology, and other sciences. Attention to the problem of well-being reflects the general desire of representatives of various scientific disciplines to study the content, structure, conditions, factors and ways of achieving a prosperous lifestyle that promotes personal self-development and maintains human health and longevity. A significant role in these scientific searches belongs to psychological studies, which examine the subjective side of well-being, i.e. an emotionally coloured integral assessment of a person, reflecting a life-course filled with meaning, positive self-attitude (selfperception), satisfaction with how one's own capabilities are realised, a sense of one's own relevance and significance for other people and society, and dominance of a positive emotional background.

The psychological development of the problem of well-being was originally based on the ideas of foreign humanistic and academic positive psychology, the founder of which was American researcher M. Seligman. He considered well-being inextricably linked with a person's lifestyle and put forward the position that participation in meaningful projects and involvement in meaningful relationships is the main source of well-being (Leontyev, 2012). Based on these ideas, C. Ryff proposed a well-known model of personal well-being, which was associated with aspirations for personal growth, self-development and self-actualisation, autonomy and self-realisation in a positive social and psychological environment when people feel satisfied with the processes and results of achieving their aspirations (Ryff, Keyes, 1995). This model was of a general psychological nature, since personal well-being was considered in it outside the specific areas of human life. Therefore, a need arose for a psychological study of the uniqueness of the content, structure, conditions, factors and ways to achieve well-being in professional, educational, family, recreational and other areas of human life. However, it should be borne in mind that the very understanding of personal well-being in a particular area depends on the national culture-specific characteristics. Therefore, a psychological study of the uniqueness of well-being in a certain area of life requires the involvement of representative samples of various cultures. 
Since professional occupations play a pivotal role in life activities of human communities, the study of the uniqueness of human well-being in a professional sphere (i.e. occupational well-being) is of particular relevance. The focus of psychological research is on the subjective side of well-being, i.e. subjective occupational well-being. Based on the above position of M. Seligman, we can conclude that the main source of subjective professional well-being is the meaning of professional activity, in which a person is engaged. The question is which exactly 'meaning' becomes the source of subjective professional well-being. According to C. Riff's model, this meaning is associated with the achievement of aspirations for personal growth, self-improvement, self-realisation and autonomy by means of professional occupations.

However, correlation of subjective professional well-being only with the above aspirations and conditions does not take into account the need for a person to realise the initial meaning of any professional activity as aimed at obtaining the results required by society, namely products, goods, technologies, cultural values, medical, educational, transport and other services, spectacular entertainment shows, etc. Understanding labour activity as aimed at achieving socially demanded results suggests that each of the participants should be aware of its compulsoriness and timeliness (Klimov, 2005). Professional activities, the results of which do not meet the expectations and requirements of society, become unclaimed; as a result, the demand for its participants is lost, and the problem of their subjective occupational well-being becomes irrelevant. Therefore, it would be incorrect to consider the assessment of personal occupational well-being without correlating it with the assessment of personal social and professional relevance.

The aim of the study was to provide a theoretical and empirical justification for the construct of subjective occupational well-being including the component of social and occupational relevance.

\section{The construct of subjective occupational well-being}

In the methodology of science, the term 'construct' is interpreted as a theoretical or axiomatic construction, concept, scheme, or configurator (Shchedrovitsky, 1995). This term is used to emphasise the activity and constructiveness of the work of scientific consciousness when new scientific concepts are introduced (Shvyrev, 2001). In psychology, the most widespread understanding is that the term 'construct' refers to something inaccessible to direct observation but inferred in a logical way based on observed signs (Cardwall, 2000). Constructs include, for example, the concepts of intelligence, attitudes, etc. (Balykhina, 2000).

Based on the above understanding, the term 'subjective occupational well-being' should also be referred to constructs. This term requires special explanation. In scientific publications, the term 'occupational well-being' is used to denote the state of personal psychological well-being in the professional sphere. However, this name covers not only the subjective side of human well-being in the professional sphere studied in psychology but also indicators of health status, physical protection from work-related dangers, decent material reward, and other non-psychological characteristics. The term that we newly propose is more strict, since it reflects only the subjective side of human well-being in the professional sphere studied by psy- 
chological methods. At the same time, the term 'subjective occupational well-being' and the term 'occupational well-being' (given the widespread use of the latter in psychological publications) are used in this paper as synonyms.

A comprehensive analytical review made by R.A. Berezovskaya considered the main results, problems and prospects of research on occupational well-being. This author showed that the theoretical basis of foreign studies of occupational well-being was C. Ryff's model mentioned above. That is, occupational well-being was associated with aspirations for personal growth, autonomy, self-development, and self-actualisation by means of a professional occupation in a favourable working environment. While the general theoretical basis laid down in C. Ryff's model was preserved, the newly developed models of occupational well-being included components that reflected the characteristics of professional activity. There were two such models. In the earlier model, which was proposed by the English psychologist P. Warr in 1990, occupational well-being was considered as a psychological structure determined by the conditions and content of the work, including four primary components, namely 'aspiration for growth and development', 'autonomy', 'competency', and 'emotional well-being'. The indices obtained for these components were then summarised in the final index - "overall functioning" characterising the subjective side of occupational well-being. The need to include the 'competency' component was determined by the fact that the acquisition of professional knowledge and skills is a necessary prerequisite for employees to successfully complete their work and experience occupational well-being. Later, the Dutch researcher J. van Horn with his colleagues (Van Horn et al., 2004), having generalised the models of C. Ryff and P. Warr, developed a multidimensional model of occupational well-being which included emotional, cognitive, behavioural, motivational, and psychosomatic components. The inclusion of the psychosomatic component in this multidimensional model was due to numerous empirical studies that proved the close relationship between somatic complaints and the level of subjective well-being. The authors of the multidimensional model showed that the emotional, motivational and behavioural components were the most contributive to occupational well-being (Berezovskaya, 2016).

Thus, the models of P. Warr and Van Horn associated the achievement of occupational well-being with the realisation of aspirations for personal self-development and autonomy subject to professional competency and favourable emotional and psychosomatic states prevailing in a comfortable working environment. However, these models did not take into account the social and occupational relevance of actors as a necessary condition for their professional well-being.

\section{The concept of personal social and occupational relevance}

The problem of personal occupational relevance is actively studied in sociology, economics, pedagogy, and other scientific disciplines. However, in psychology, this problem has so far received much less attention. Among the few works on this issue, we think it necessary to note the study made by Ye.V. Kharitonova (2014) who proposed the concept of 'personal social and professional relevance'. The theoretical background of the concept, as its author noted, was formed by the studies of the phenomenon of personal relevance in the framework of exis- 
tential and subjective approaches in foreign and domestic psychology, respectively. These studies pointed to the aspiration to realise one's own potential not only for one's own sake but also for the sake of 'someone else', 'outside of one's own self'. At the same time, the authors emphasise that it is labour that most of all gives individuals the opportunity to comprehend their relevance and significance for other people and society ${ }^{1}$. Based on this background, Ye.V. Kharitonova points out that in order to realise and experience personal social and occupational relevance, it is critically important to strive to reveal one's own potential not only for one's own sake but also for 'someone else'. The concept of personal social and occupational relevance expresses the following set of professional self-esteems: (1) in the sphere of self-consciousness: "I as a professional"; (2) in the professional sphere: "I as a professional in the eyes of the professional community"; and (3), in the sphere of communication: "I as a professional in the eyes of my family, friends and other people". Occupational relevance in this concept is comprehended at the following three levels: (1) if the activity is carried out for the sake of achieving one's own material benefit and pursuing individual career aspirations, then comprehension is manifested at the egocentric level; (2) if the activity is carried out for the welfare of one's family and friends, then comprehension is manifested at the group-centric level; and (3), if the activity is carried out for the benefit of each and every one, close friends and unfamiliar people, even future generations, then comprehension is manifested at the pro-social level (Kharitonova, 2014).

Thus, there are good grounds for believing that subjective occupational well-being cannot be considered without correlation with assessments of personal social and professional relevance.

\section{Social and occupational relevance as a component of the construct of subjective occupational well-being: empirical testing}

The previous sections of the article described the theoretical prerequisites for the inclusion of the component of personal social and occupational relevance in the construct of subjective occupational well-being. The empirical prerequisites were the results of our previous studies, which revealed close positive correlation between the self-esteems of subjective occupational well-being and social and occupational relevance among specialists involved in hazardous activities, e.g. pilots, firefighters, rescuers, locomotive crew drivers, etc. (Bessonova, Bronevitsky, 2016; Bessonova, Oboznov, Petrovich, 2018) and representatives of ordinary professions, e.g. employees of territorial tax authorities (Petrovich, Oboznov, Kozhanova, 2018). These prerequisites formed the basis for an empirical study of social and occupational relevance as a component of the construct of subjective occupational well-being.

According to the purpose of the study set in the Introduction, the following tasks were identified:

- to reveal the dependence of indices of occupational well-being on the level of social and occupational relevance;

${ }^{1}$ In this connection, it is appropriate to cite the idea of Z. Freud that "...there is no other activity that would attach a person to reality so much as labor" (Ulikh, 1994. P. 17). 
- to confirm empirically the inclusion of social and occupational relevance as an independent component of the construct of subjective occupational well-being.

According to the above tasks, the following hypotheses were formulated:

- there is a direct dependence of indices of occupational well-being on the level of social and occupational relevance;

- a set of indicators of social and occupational relevance form an independent component of the construct of subjective occupational well-being.

\section{Methods}

Techniques. To diagnose social and occupational relevance, we used The Professional Demand Questionnaire (PDQ) (Kharitonova, 2014), which included eight scales: (1) "Satisfaction with the Realisation of Professional Potential"; (2) "Affiliation with the Professional Community"; (3) "Experience of Occupational Relevance"; (4) "Professional Competency"; (5) "Professional Authority"; (6) "Estimated Results of Professional Activity"; (7) "Attitude of Others"; and (8) "Self-Attitude". Calculations were made in relation to the indices of each scale as well as their total index of social and occupational relevance.

Three questionnaires were used to diagnose subjective professional well-being.

Aspirations for professional growth, autonomy and work in a favourable working environment, satisfaction with the competency level and professional achievements were diagnosed by means of The Occupational Well-Being Inventory (OWBI), which was tested in the study by Ye.I. Rut (2016). This inventory is a modified Russian version of The Ryff Scales of Psychological Well-Being (Zhukovskaya, Troshikhina, 2011). Its scales were tested for compliance of their criterion validity and synchronous reliability with the scales of the indicated Russian version. The questionnaire included six scales: (1) "Professional Growth"; (2) "Professional Goals"; (3) "Positive Relations in the Team"; (4) "Autonomy in Professional Activity"; (5) "Satisfaction with the Competency Level"; and (6) "Satisfaction with Professional Achievements". Thus, the theoretical basis of the questionnaire was the concept of personal well-being specified to the professional sphere as the realised aspiration for personal growth and autonomy in a favourable working environment. The need to correlate occupational well-being with the assessment of personal social and occupational relevance was not considered.

Taking into account the significant contribution of the emotional component to the achievement of subjective occupational well-being noted in Van Horn's multidimensional model, we paid special attention to its components in our study. To diagnose the prevalent emotional state as a necessary component of subjective occupational well-being, The Prevalent Positive Emotional State Questionnaire (PPESQ) was used, which included six scales (Kulikov, 2003): (1) "Active/Passive Attitude to Life Situations": high scores indicated the severity of an active, optimistic attitude to a certain life situation, readiness to overcome obstacles, belief in one's own abilities; (2) "High/Low Tonus": high scores indicated an increased ability to be active and expend energy, to react stenically to difficulties; (3) "Calmness/Anxiety": high scores indicated confidence in one's own abilities and capabilities; (4) "Stable/ Unstable Emotional Tone": high scores indicated the predominance of an even positive emotional tone, a calm flow of emotional processes; (5) "Satisfaction/Dis- 
satisfaction with Life": high scores indicated satisfaction with life as a whole, its course, self-realisation; and (6) "Positive/Negative Self-Perception": high scores indicated a developed ability to perceive oneself with all one's demerits and a reduced criticality of self-esteem. Calculations were carried out in relation to the indices of each scale, while it was not required to calculate the total index in this questionnaire. It was assumed that occupational well-being was characterised by the prevalence of a positive emotional state, i.e. its high scores on each scale of The PPESQ.

In addition, to diagnose the emotional state during the periods of professional activity, single-scale questionnaires, namely The Utrecht Work Engagement Scale (UWES-17) and Dutch Boredom Scale (DUBS) in Russian adaptation (Schaufeli, Diystra, Ivanova, 2015) were used.

Statistical analysis. The obtained empirical data were processed and analysed by means of the one-way analysis of variance (ANOVA) and factor analysis (principal component analysis, varimax rotation). The ANOVA was used to test the hypothesis about the dependence of indices of occupational well-being on the level of indices of social and occupational relevance. The factor analysis was used to test the hypothesis about the inclusion of indices of personal social and occupational relevance as an independent component in the construct of subjective professional well-being.

Participants. The study involved 285 employees of Russian territorial tax authorities. Their age range was $22-62$ years, with $25 \%$ of the sample on the right side of thirty. The sample included $70 \%$ of women and $30 \%$ of men.

Their employment records in the tax service ranged from 1 to 34 years, including less than three years in $18 \%$ of the sample. By official positions, $77 \%$ were employees and 23\% were heads of departments and their deputies. By areas of activity, the sample included those who provide information security, debt settlement, bankruptcy procedures, heads and employees of the desk audit, taxpayer, internal control and financial support departments. In general, the work of employees and heads of territorial tax authorities, as well as all other state civil servants, is regulated by federal law and internal regulatory and procedural documents. These documents regulate the terms, responsibilities and general procedures for managers and employees but their work is not monotonous and trivial. In fact, they have to constantly deal with non-standard tasks and find ways to resolve work-specific situations and problems. Continuous changes in tax legislation along with the active introduction of modern information technologies, the transition to remote ways of interacting with taxpayers make it necessary for these managers and employees to constantly improve professional competencies, knowledge and skills.

\section{Results}

ANOVA Results. For the ANOVA test, the independent variable was the total index of The PDQ. Using the percentile method, we divided the surveyed sample into 3 groups with a low (less than the $33^{\text {rd }}$ percentile), medium (from the $33^{\text {rd }}$ to $67^{\text {th }}$ percentile) and high (more than the $67^{\text {th }}$ percentile) level of the total index reflecting the severity of employees' assessments of their social and occupational relevance. The dependent variables were: the total index and indices of each scale of The OWBI, indices of the scales of The PPESQ as well as indices of the UWES-17 and DUBS scales. 
According to the ANOVA results, the employees with a high level of the independent variable, compared with the employees with a medium and low level of the this variable, had significantly higher scores on all the dependent variables, i.e. indices of occupational well-being, prevalent emotional state, the UWES-17 scale, and the lowest scores on the DUBS scale. For illustrative purposes, below are data on the severity of aspirations for professional growth (Figure 1), tonus (Figure 2), and work engagement (Figure 3) among the employees with different levels of the total index of social and occupational relevance.

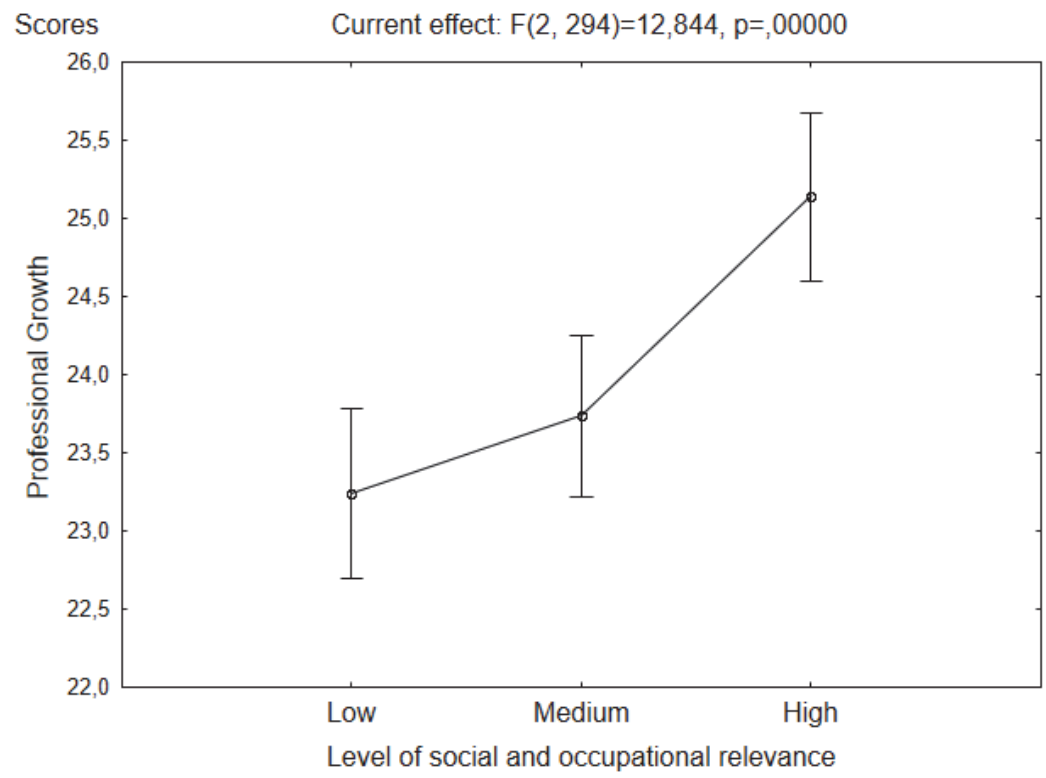

Figure 1. The "Professional Growth" scale index depending on the level of social and occupational relevance (total index, scores)

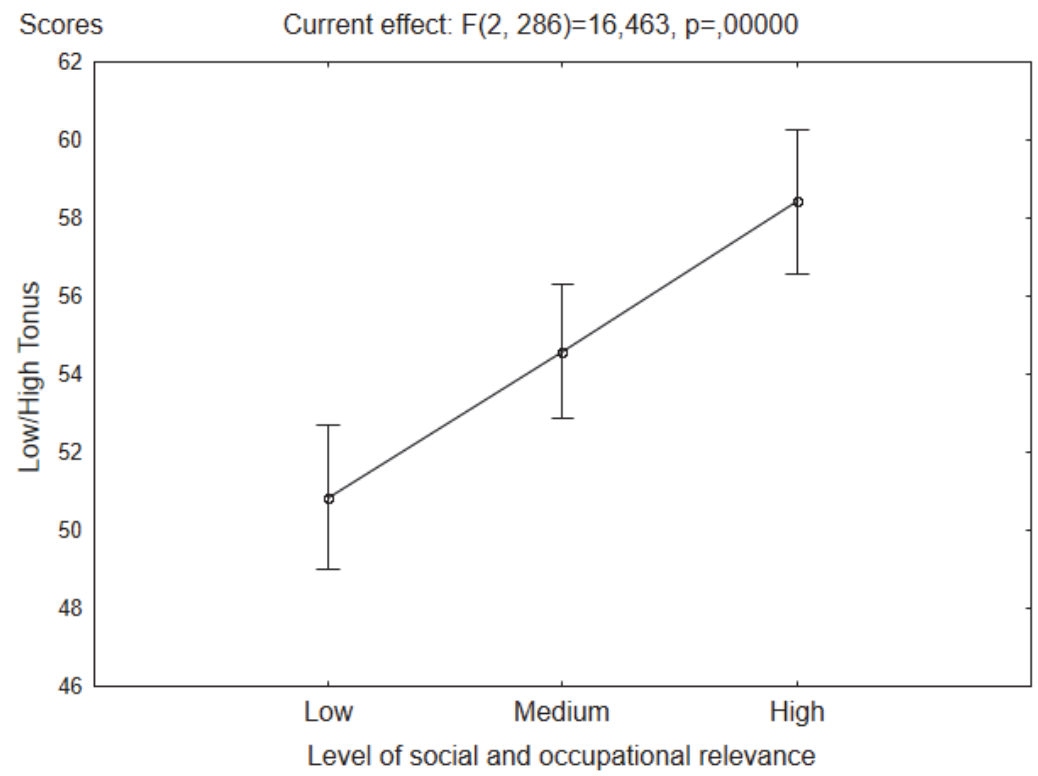

Figure 2. The "Low/High Tonus" scale index depending on the level of social and occupational relevance (total index, scores) 


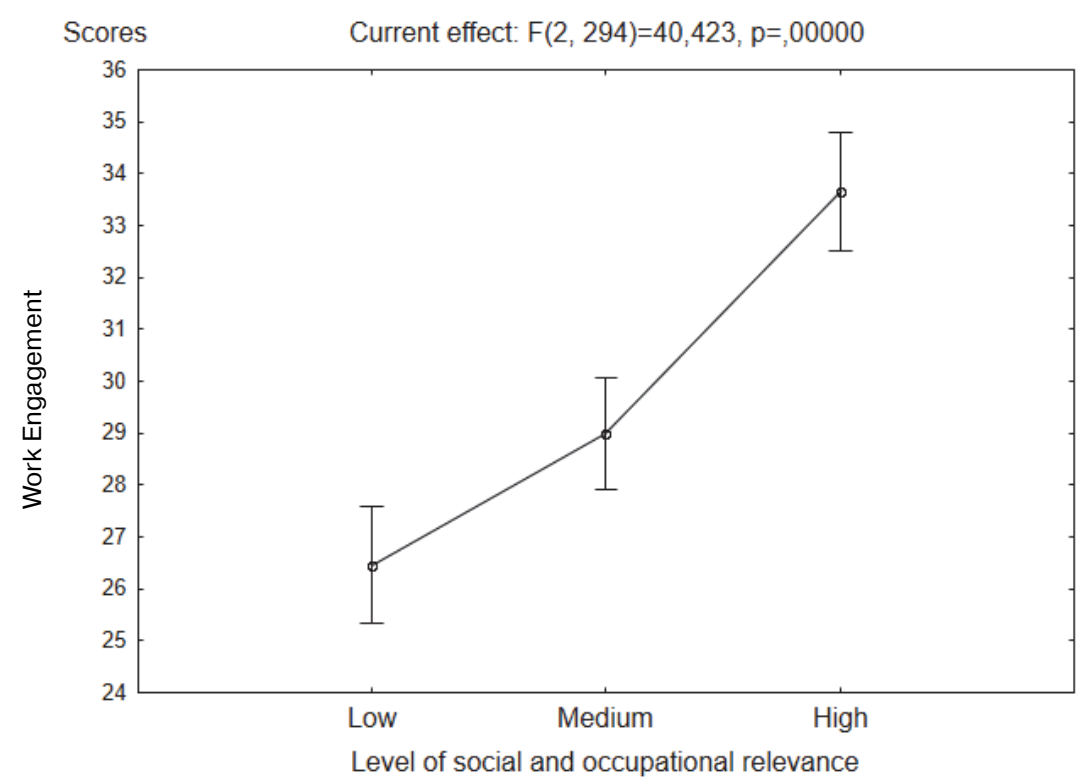

Figure 3. The "Work Engagement" scale index depending on the level of social and occupational relevance (total index, scores)

Thus, the employees who most highly estimate their social and occupational relevance are most characterized by such manifestations of occupational well-being as expressed aspiration for the achievement of professional goals, professional growth and control of their working environment, satisfaction with their achievements and competency level, positive relationships in the team (according to The OWBI). Such employees are distinguished by an active attitude to life situations, high tonus, calmness, stable positive emotional tone, satisfaction with life, positive selfperception (according to The PPESQ) as well as hight work engagement and lack of boredom of work (according to the UWES-17 and DUBS scales).

The above results confirmed the hypothesis that the severity of indices of occupational well-being, prevalent positive emotional state and work engagement depend on the level of social and occupational relevance.

Factor Analysis Results. A 3-factor model was chosen, which made it possible to explain $60 \%$ of the data variance. For a meaningful interpretation of each factor, variables with a factor weight $>.70$ were taken into account (see the Table).

The first factor (27\% of the variance explained), called "Social and Occupational Relevance", with factor weights $>.70$ included variables that corresponded to the six scales of The PDQ: "Professional Authority" (factor weight $=.85$ ), "Estimated Results of Professional Activity" (factor weight $=.82$ ), "Attitude of Others" (factor weight $=.81$ ), "Satisfaction with the Realised Professional Potential" (factor weight $=.81$ ), "Affiliation with the Professional Community" (factor weight $=.80$ ), and "Self-Attitude" (factor weight $=.77$ ). At the same time, the factor weights of the other two variables in The PDQ: "Experience of Occupational Relevance" (factor weight $=.66$ ) and "Professional Competency" (factor weight $=.66$ ) were extremely close to the required value of .70 .

The second factor (19\% of the variance explained), called "Prevalent Positive Emotional State" with factor weights $>.70$ included the following five of the six variables from The PPESQ: "Stable/Unstable Emotional Tone" (factor weight $=.82$ ), 
"Positive/Negative Self-Perception" (factor weight $=.82$ ), "Satisfaction/Dissatisfaction with Life" (factor weight $=.82$ ), "Calmness/Anxiety" (factor weight $=.81$ ), "Low/High Tonus" (factor weight $=.72$ ).

Table

Means (M), standard deviations (SD) and factor analysis results

\begin{tabular}{|c|c|c|c|c|c|}
\hline \multirow[t]{2}{*}{ Variables } & \multirow[t]{2}{*}{ M } & \multirow[t]{2}{*}{ SD } & \multicolumn{3}{|c|}{$\begin{array}{l}\text { Factor loadings (varimax raw). } \\
\text { Extraction: principal components }\end{array}$} \\
\hline & & & Factor1 & Factor 2 & Factor 3 \\
\hline \multicolumn{6}{|l|}{ Social and Occupational Relevance (PDQ) } \\
\hline $\begin{array}{l}\text { Satisfaction with the Realisation of Profes- } \\
\text { sional Potential }\end{array}$ & 26.60 & 4.58 & .81 & .17 & .22 \\
\hline Affiliation with the Professional Community & 28.24 & 3.95 & .80 & .09 & .27 \\
\hline Experience of Occupational Relevance & 28.34 & 4.00 & .66 & .38 & .05 \\
\hline Professional Competency & 26.13 & 5.17 & .66 & .30 & .22 \\
\hline Professional Authority & 24.68 & 3.56 & .85 & .13 & .16 \\
\hline Estimated Results of Professional Activity & 30.15 & 3.45 & .82 & .23 & .26 \\
\hline Attitude of Others & 28.74 & 3.73 & .81 & .07 & .05 \\
\hline Self-Attitude & 25.77 & 3.73 & .77 & .23 & .18 \\
\hline \multicolumn{6}{|l|}{ Occupational Well-Being (OWBI) } \\
\hline Autonomy in Professional Activity & 21.32 & 2.72 & .10 & .29 & .28 \\
\hline Satisfaction with the Competency Level & 22.09 & 3.24 & .46 & .39 & .50 \\
\hline Satisfaction with the Level of Achievements & 22.12 & 3.32 & .54 & .31 & .38 \\
\hline Professional Growth & 24.03 & 2.80 & .08 & .12 & .76 \\
\hline Professional Goals & 23.19 & 3.34 & .30 & .17 & .75 \\
\hline Positive Relations in the Team & 23.46 & 3.41 & .39 & .14 & .28 \\
\hline \multicolumn{6}{|l|}{ Prevalent Positive Emotional State (PPESQ) } \\
\hline Active/Passive Attitude to Life Situations & 47.75 & 12.22 & .26 & .13 & .71 \\
\hline High/Low Tonus & 54.73 & 9.39 & .13 & .72 & .20 \\
\hline Calmness/Anxiety & 56.69 & 9.39 & .28 & .81 & .17 \\
\hline Stable/Unstable Emotional Tone & 58.30 & 9.05 & .16 & .82 & .17 \\
\hline Satisfaction/Dissatisfaction with Life & 60.38 & 9.54 & .35 & .82 & .17 \\
\hline Positive/Negative Self-Perception & 58.30 & 10.25 & .01 & .82 & -.09 \\
\hline \multicolumn{6}{|c|}{ Work Engagement (UWES-17) and Boredom of Work (DUBS) } \\
\hline Work Engagement & 29.73 & 6.31 & .35 & .10 & .72 \\
\hline Boredom of Work & 11.93 & 2.87 & -.19 & -.44 & -.15 \\
\hline Expl. Var. & - & - & 6.02 & 4.21 & 3.18 \\
\hline Prp. Totl. & - & - & .27 & .19 & .14 \\
\hline
\end{tabular}

Note. Variables with a factor weight $>.70$ are in italics and bold.

The third factor (14\% of the variance explained), called "Aspiration for Professional Growth", with factor weights $>.70$ included the two variables "Professional Growth" (factor weight $=.76$ ) and "Professional Goals" (factor weight $=.75$ ) - from The PDQ, as well as the variable "Work Engagement" (factor weight $=.72$ ) from the single-scale questionnaire of the same title and the variable "Active/Passive Attitude to Life Situations" (factor weight $=.71$ ) from The PPESQ. The fact that one factor included the listed four variables from the three different questionnaires can be interpreted this way: as a result of active aspirations of the employees towards professional growth and achievement of professional goals, they experienced enthusiasm for their work. Note that the variable 
"Autonomy" from The OWBI had a factor weight of .28, which led to the exclusion of the term 'autonomy' from the previously assumed name of Factor 3 "Aspiration for Professional Growth and Autonomy". The fact is that The OWBI suggested the following understanding of autonomy: "The scale of 'Autonomy in professional activity' and independence in professional actions is the ability to withstand social pressure and act according to personal settings and standards regardless of opinions of colleagues and surrounding people. Persons who have high scores on this scale estimate themselves and their behaviour based on personal professional beliefs. Low scores on this scale indicate conformism and exposure to social pressure during the performance of work; concern over the expectations and estimates of colleagues and managers, decision-making based on the opinions of other people" (Rut, 2016. P. 164). Our study involved representatives of state civil servants - employees of territorial tax authorities. As noted above, their work is carried out strictly within the framework of regulatory documents that determined the terms, responsibilities and general procedures for managers and employees. Therefore, the understanding of autonomy adopted in The OWBI, especially the interpretation of high autonomy rates, fell well short of the demands of the professional activity of the tax officials. Ultimately, this led to a low factor weight of the variable "Autonomy in Professional Activity" and its exclusion from the name of Factor 3.

Thus, the factor analysis results allowed us to confirm the second hypothesis of our study: the totality of employees' estimates of their social and occupational relevance was an independent component of the construct of subjective occupational well-being.

\section{Discussion}

The revealed direct dependence of the indices of the prevalent emotional state, work engagement and aspiration for professional growth on the level of estimates of social and occupational relevance pointed to a special role of employees' understanding of their social and psychological relevance for achieving subjective occupational well-being. If we proceed from M. Seligman's provision on the participation of people in meaningful projects and their involvement in meaningful relationships as the main source of their well-being, the revealed direct dependence testified that, for the examined tax service employees, the meaning of their professional activity is not associated only with the above estimates. In other words, the meaning of professional activity as a source of subjective occupational well-being cannot be reduced only to employees' realisation of their individual aspirations for professional growth, satisfaction with professional achievements and relationships in the work team, or experiences of stable positive emotional states and work engagement, as it is accepted in existing models of occupational well-being. According to the results obtained, the achievement of subjective occupational well-being is no less associated with the meaningfulness of the employees' own social and occupational relevance.

Thus, according to the results of our empirical study, the following conclusions can be drawn:

- the indices of subjective occupational well-being, including the prevalent emotional state, work engagement, aspiration for professional self-actualisation 
and growth, directly depend on the level of estimates of social and occupational relevance;

- the totality of employees' estimates of their social and professional relevance form an independent component of the construct of subjective occupational well-being;

- the construct of subjective professional well-being includes three independent but, at the same time, interrelated components. The first component reflects the employees' estimates of their social and occupational relevance; the second and the third components reflect their estimates of the prevalent emotional state and the severity of aspirations for professional self-actualisation and growth, respectively. However, it should be emphasised that, for determining the limits of applicability of this result, it is necessary to conduct further research involving representatives of other professions.

\section{Conclusion}

If we consider the practical significance of studies on subjective professional well-being, including the present study, then, in our opinion, it consists in applying their results for preserving occupational health and career longevity of people, their interest in professional self-actualisation, development and maintenance of a positive attitude to work, as well as for creating favourable relations in organisations and, most importantly, for including individuals in the human realm so that they could realise their social mission. In this regard, two areas of further research on subjective occupational well-being seem to be relevant.

One area is the further elaboration of the ideas of the resource approach for developing and maintaining subjective occupational well-being (Schaufeli, Bakker, Van Rhenen, 2009, and others). The term 'resources' in the broad sense of the word is used to denote some universal characteristics of any artefacts, natural phenomena and living organisms, which are considered as means of solving certain problems. From our point of view, such a characteristic is a specially created and/or initially inherent in these means stock of opportunities for performing these tasks. This stock (of resources), being limited at any given moment, can be distributed in different ways between different tasks, be spent and accumulated again. That is, using the term "resources", we can consider any object, process or organism in instrumental function, namely, as having a limited and, at the same time, variable stock of possibilities for solving certain problems (Oboznov, 2013).

In relation to the task of achieving subjective professional well-being, recent studies have identified internal and external factors that have a stock of opportunities (resources) for developing subjective occupational well-being of employees. In the synthetic Job Demands-Resources (JD-R) model, job demands (i.e. those of the profession and working conditions) affect the work performed indirectly, using the resources of the employee's personality and the resources of the working environment. A peculiar feature of the JD-R model is its professional specificity: which specific resources mediate the influence of job demands will depend on the specific work environment (Bakker, Demerouti, 2007). However, some resources appear to be universal; their positive impact on the level of occupational well-being is noted in cross-occupational studies (Brauchli et al., 2013). Resources that contribute to 
maintaining occupational well-being of employees include occupational prestige, support of colleagues and management, recognition of professional authority and high qualification status, enthusiasm for the profession (Schaufeli, Bakker, Van Rhenen, 2009), professional identity (MacKinnon, Langford, 2005). It is necessary to create such working conditions for a person that would contribute to the actualisation of these resources to achieve and sustainably maintain subjective occupational well-being.

The other direction is the study of subjective occupational well-being as part of the cross-cultural approach. The practical importance of addressing the crosscultural approach is determined by the increasing prevalence of organisations, which include representatives of different cultures and ethnic groups. The most important elements of each culture are the prototypes of personalities belonging to it. As H.C. Triandis noted, in a description of any culture, the emphasis is laid on prototypes, which contain the ideas prescribed by the culture about the values, beliefs, relationships, behaviours of the people committed to it. The personality prototype provides guidance for people to develop personal entities that determine commitment to a particular culture (Triandis, 2007).

The issue of descriptions of subjective occupational well-being contained in prototypes of different cultures remains largely unexplored. Given the fact that the professional sphere involves representatives of different cultures and ethnic groups, the relevance of the cross-cultural approach to research on subjective occupational well-being becomes apparent.

Acknowledgements and Funding. The study was supported by the Russian Foundation for Basic Research, Project No. 18-013-01021a.

\section{References}

Bakker, A.B., \& Demerouti, E. (2007). The Job Demands-Resources model: State of the art. Journal of Managerial Psychology, 22, 309-328.

Balykhina, T.M. (2000). Slovar Terminov i Ponyatiy Testologii. Moscow: MGUP Publ. (In Russ.) Berezovskaya, R.A. (2016). Occupational well-being: Problems and prospects of psychological studies. Psikhologicheskiye Issledovaniya, 9(45), 2. Retrieved from http://psystudy.ru/index.php/num/2016v9n45/1232-berezovskaya45.html (In Russ.)

Bessonova, Yu.V., \& Bronevitsky, G.G. (2016). Psikhologicheskoye blagopoluchiye u predstaviteley opasnykh professiy. In: M.I. Volovikova, A.L. Zhuravlev, \& N.Ye. Kharlamenkova (Eds.), Psikhologicheskiye Issledovaniya Lichnosti: Istoriya, Sovremennoye Sostoyaniye, Perspektivy (pp. 327-351). Moscow: Institut psikhologii RAS Publ. (In Russ.)

Bessonova, Yu.V., Oboznov, A.A. \& Petrovich, D.L. (2018). Psikhologicheskoye blagopoluchiye professionala v organizatsiyakh povyshennogo riska. In: A.N. Anokhin, A.A. Oboznov, P.I. Paderno, S.F. Sergeyev (Eds.), Chelovecheskiy Faktor v Slozhnykh Tekhnicheskikh Sistemakh i Sredakh (ERGO-2018): Conference Prosideengs (pp. 627-635). Saint Petersburg: ETU “LETI”, Interregional Ergonomic Association. (In Russ.)

Brauchli, R., Schaufeli, W.B., Jenny, G.J., Füllemann, D., \& Bauera, G.F. (2013). Disentangling stability and change in job resources, job demands, and employee well-being - A three-wave study on the Job-Demands Resources model. Journal of Vocational Behavior, 83(2), 117-129.

Cardwall, M. (2000). A-Z. Psychology. Moscow: FAIR-PRESS Publ.

Kharitonova, Ye.V. (2014). Psikhologiya Sotsialno-Professionalnoy Vostrebovannosti Lichnosti. Moscow: Institut psikhologii RAS Publ. (In Russ.)

Klimov E.A. (2005). Psikhologiya Professionalnogo Samoopredeleniya. Moscow: Akademiya Publ. (In Russ.) 
Kulikov, L.V. (2003). Rukovodstvo k Metodikam Diagnostiki Psikhicheskikh Sostoyaniy, Nastroyeniy i Sfery Chuvstv. Opisaniye Metodik, Instruktsii po Primeneniyu. Saint Petersburg: SPSU Publ. (In Russ.)

Leontyev, D.A. (2012). Positive Psychology: An Agenda for the New Century. Psychology. Journal of the Higher School of Economics, 9(4), 36-58. (In Russ.)

MacKinnon, N.J., \& Langford, T. (1994). The meaning of occupational prestige scores: A social psychological analysis and interpretation. The Sociological Quarterly, 35(2), 215-245. https://doi.org/10.1111/j.1533-8525.1994.tb00408.x

Oboznov, A.A. (2013). Vnutrenniye i vneshniye resursy psikhicheskoy regulyatsii deyatel'nosti. In: A.L. Zhuravlev, E.A. Sergiyenko (Eds.), Chelovek, Subyekt, Lichnost v Sovremennoy Psikhologii: Conference Proceedings (vol. 1, pp. 561-563). Moscow: Institut psikhologii RAS Publ. (In Russ.)

Petrovich, D.L., Oboznov, A.A., \& Kozhanova, I.V. (2018). Professional demand as a factor of professional psychological well-being. Organizatsionnaya Psikhologiya i Psikhologiya Truda, 3(4), 115-145. (In Russ.).

Rut, Ye.I. (2016). Professionalnoye Blagopoluchiye Sotrudnikov Kommercheskikh Organizatsiy: Kriterii i Metodika Otsenki: MA in Psychology Thesis. Saint Petersburg: SPbSU Publ. (In Russ.)

Ryff, C.D., \& Keyes, C.L.M. (1995). The structure of psychological well-being revisited. Journal of Personality and Social Psychology, 69, 719-727.

Schaufeli, W.B., Bakker, A.B., \& Van Rhenen, W. (2009). How changes in job demands and resources predict burnout, work engagement, and sickness absenteeism. Journal of Organizational Behavior, 30, 893-917.

Schaufeli, W.B., Diystra, P., \& Ivanova, T.Yu. (2015). Uvlechennost Rabotoy: Kak Nauchitsya Lyubit Svoyu Rabotu i Poluchat ot Neyo Udovolstviye. Moscow: Kogito-tsentr Publ. (In Russ.)

Shchedrovitsky, G.P. (1995). Skhema mysledeyatelnosti: Stroyeniye, smysl, soderzhaniye. In: G.P. Shchedrovitsky, Selected Works (pp. 281-298). Moscow: Shkola Kulturnoy Politiki Publ. (In Russ.)

Shvyrev, V.S. (2010). Konstrukt. In: V.S. Stopin, A.A. Guseynov, G.Yu. Semigin, A.P. Ogurtsov (Eds.), Novaya Filosofskaya Entsiklopediya. $2^{\text {nd }}$ ed. Moscow: Mysl Publ. (In Russ.)

Triandis, H. (2007). Culture and Social Behaviour. Moscow: FORUM. (In Russ.).

Ulikh E. (1994). Psikhologiya truda v izmenyayushchemsya industrialnom mire. Inostrannaya Psikhologiya, 2(1), 13-20. (In Russ.)

Van Horn, J.E., Taris, T.W., Schaufeli, W.B., \& Schreurs, P.J.G. (2004). The structure of occupational well-being: A study among Dutch teachers. Journal of Occupational and Organizational Psychology, 77, 365-375. https://doi.org/10.1348/0963179041752718

Warr, P. (2013). How to think about and measure psychological well-being. In: M. Wang, R.R. Sinclair, \& L.E. Tetrick (Eds.), Research Methods in Occupational Health Psychology: Measurement, Design and Data Analysis (pp. 76-90). New York: Psychology Press, Routledge.

Zhukovskaya, L.V., \& Troshikhina, Ye.G. (2011). K. Ryff's Scale of Psychological Well-Being. Psikhologicheskiy Zhurnal, 32(2), 82-93. (In Russ.)

\section{Article history:}

Received: 5 December 2019

Revised: 7 April 2020

Accepted: 15 April 2020

\section{For citation:}

Oboznov, A.A., Petrovich, D.L., Kozhanova, I.V., \& Bessonova, Yu.V. (2020). The construct of subjective occupational well-being: Russian sample testing. RUDN Journal of Psychology and Pedagogics, 17(2), 247-262. http://dx.doi.org/10.22363/2313-1683-202017-2-247-262 


\title{
Bio notes:
}

Alexander A. Oboznov, Full Doctor of Psychology, Professor, is chief researcher of Laboratory of Labor Psychology, Ergonomics, Industrial and Organizational Psychology, Institute of Psychology of Russian Academy of Sciences (Moscow, Russia). E-mail: aao46@mail.ru

Daria L. Petrovich, Ph.D. in Psychology, is Associate Professor in Psychology Department, State Academic University for Humanities (Moscow, Russia). E-mail: dlpe@mail.ru

Irina V. Kozhanova, Ph.D. in Psychology, is Associate Professor, Vice-Rector for Academic Affairs, Federal State Institute of Advanced Finance Professional Training "Federal Tax Service Training Institute” (Nizhny Novgorod, Russia). E-mail: i_koj@mail.ru

Yulia V. Bessonova, Ph.D. in Psychology, is researcher of Laboratory of Labor Psychology, Ergonomics, Industrial and Organisational Psychology, Institute of Psychology of Russian Academy of Sciences (Moscow, Russia). E-mail: farandi@mail.ru

\section{DOI 10.22363/2313-1683-2020-17-2-247-262 Исследовательская статья}

\section{Конструкт субъективного профессионального благополучия: верификация на российской выборке}

\section{А.А. Обознов ${ }^{1}$, Д.Л. Петрович ${ }^{2}$, И.В. Кожанова ${ }^{3}$, Ю.В. Бессонова ${ }^{1}$}

\author{
${ }^{1}$ Институт психологии Российской академии наук \\ Российская Федераиия, 129366, Москва, ул. Ярославская, д. 13, корп. 1 \\ ${ }^{2}$ Государственный академический университет гуманитарных наук \\ Российская Федерация, 119049, Москва, Мароновский пер., 26 \\ ${ }^{3}$ Приволжский институт повышения квалификации ФНС России \\ Российская Федерация, 603950, Нижний Новгород, ул. Грузинская, 48
}

\begin{abstract}
Аннотация. Субъективное профессиональное благополучие, по мнению авторов статьи, относится к числу ключевых условий профессионального здоровья и долголетия современного человека. Вместе с тем в существующих моделях достижение профессионального благополучия соотносится с реализацией человеком устремлений к личностному саморазвитию и автономности при условии профессиональной компетентности, доминирования благоприятного эмоционального и психосоматического состояния в комфортной рабочей среде, в то время как социально-профессиональная востребованность участников деятельности в качестве фактора их профессионального благополучия в этих моделях не учитывается, хотя любая профессиональная деятельность исходно нацелена на получение требуемых обществом результатов. Деятельность, результаты которой не соответствуют ожиданиям и требованиям общества, становится невостребованной, утрачивается востребованность ее участников, а проблема их субъективного профессионального благополучия теряет актуальность. Поэтому оценка человеком своего профессионального благополучия не может рассматриваться вне соотнесения с оценкой собственной социально-профессиональной востребованности. Как показано в статье, важно также учитывать этнокультурную обусловленность понимания благополучия человека. В этой связи целью исследования явилось теоретикоэмпирическое обоснование конструкта субъективного профессионального благополучия, включающего компонент социально-профессиональной востребованности, на российской выборке. Для проверки этого положения проведено эмпирическое исследование с участием 285 сотрудников территориальных налоговых органов России. Их трудовой стаж в налоговой службе составлял от 1 года до 34 лет, в том числе менее 3 лет - 18 \% выборки. Возраст - от 22 до 62 лет, в том числе в возрасте менее 30 лет - $25 \%$. Женщины составили $70 \%$, мужчины 30 \% выборки. В исследовании использовались опросник социально-профессиональной вос-
\end{abstract}


требованности личности (Kharitonova, 2014), методика оценки профессионального благополучия (Rut, 2016), опросник доминирующего эмоционального состояния личности (Kulikov, 2003), опросники «Увлеченность работой» и «Скука от работы» (Schaufeli, Diystra, Ivanova, 2015). Для обработки данных применялись методы факторного анализа (метод главных компонент, вращение варимакс) и однофакторного дисперсионного анализа ANOVA. По результатам факторного анализа установлено, что вновь предлагаемый конструкт субъективного профессионального благополучия включает три самостоятельных и взаимосвязанных компонента. Первый компонент ( $27 \%$ объясненной дисперсии) содержал совокупность самооценок сотрудников, которые отражали их осознание своей социально-профессиональной востребованности: «Я как компетентный и востребованный профессионал». Второй компонент (19\%) содержал самооценки, которые отражали степень устойчивого доминирования позитивного эмоционального состояния личности. Третий компонент (14 \%) содержал самооценки, которые отражали степень реализации сотрудниками своих устремлений к профессиональному росту, удовлетворенности профессиональными достижениями и отношениями в рабочем коллективе. Обоснованы два направления дальнейших исследований проблемы субъективного профессионального благополучия. Первое направление - дальнейшая разработка идей ресурсного подхода для развития и поддержания субъективного профессионального благополучия работников (Schaufeli, Bakker, Van Rhenen, 2009). Второе - исследования в рамках кросс-культурного, а также кросс-профессионального (Brauchli et al., 2013) подходов.

Ключевые слова: субъективное профессиональное благополучие, социальнопрофессиональная востребованность личности, конструкт, налоговая служба

Благодарности и финансирование. Исследование выполнено при финансовой поддержке РФФИ, проект № 18-013-01021а.

\section{История статьи:}

Поступила в редакцию: 5 декабря 2019 г.

Принята к печати: 15 мая 2020 г.

\section{Для цитирования:}

Oboznov A.A., Petrovich D.L., Kozhanova I.V., Bessonova Yu.V. The construct of subjective occupational well-being: Russian sample testing // Вестник Российского университета дружбы народов. Серия: Психология и педагогика. 2020. Т. 17. № 2. С. 247-262. http://dx.doi.org/10.22363/2313-1683-2020-17-2-247-262

\section{Сведения об авторах:}

Обознов Александр Александрович, доктор психологических наук, профессор, главный научный сотрудник лаборатории психологии труда, эргономики, инженерной и организационной психологии, Институт психологии РАН (Москва, Россия). Е-mail: aao46@mail.ru

Петрович Дарья Леонидовна, кандидат психологических наук, доцент факультета психологии, Государственный академический университет гуманитарных наук. E-mail: dlpe@mail.ru

Кожанова Ирина Викторовна, доцент, проректор по учебной работе, Приволжский институт повышения квалификации ФНС России (Нижний Новгород, Россия). Е-mail: i_koj@mail.ru

Бессонова Юлия Владимировна, кандидат психологических наук, научный сотрудник лаборатории психологии труда, эргономики, инженерной и организационной психологии, Институт психологии РАН (Москва, Россия). E-mail: farandi@mail.ru 